\title{
Women labor force participation in Pakistan: a survey \\ Huzaifa Sarfaraz
}

University of Karachi

Corresponding Author Email: huzaifa.socio@gmail.com

\begin{abstract}
Background: Pakistan has least growing economy in Asia; with semi-industrialized economy that backs on agriculture, industry and services. Although since 2005 the gross domestic product (GDP) has been growing an average 5 percent a year; which is not enough to keep up with fast population growth. One of the factor behind low economic growth is less female labor force participation. The present study was conducted to look for the reasons behind this low pace of participation from half part of the population.

Methodology: Present study has descriptive design as the sole purpose was to gain new insights of the phenomena. Survey was conducted using convenient sampling; comprising of 160 responses, since the respondents were selected because they were easily accessible to the researcher. No statistical test has been applied on the data, as this study is only representing the differences in responses.

Results: Results demonstrated that female youth of Pakistan is enthusiastic about being economically independent but due to social-cultural limitations and lack of support from government it would become difficult for them to achieve their goals.

Conclusion: This study came up to the conclusion that women in Pakistan are motivated and ready to be part of labor force but due to socio-cultural hindrances they are failing to do so.
\end{abstract}

\section{Keywords}

Pakistan, Female youth, Labor force participation, Low Economic Development.

\section{Introduction}

Labor force participation is the rate of working population of any country. This includes the section of population who are currently employed or seeking employment, those who are still undergoing their education are not included in the labor force (Mincer, 1962). This means that this group of population is the one who runs the economy of the country. According to report of Pakistan Bureau of Statistics (2017), the number of men in the country stand at $106,449,322$ while the number of women are $101,314,780$. The total population of Pakistan stands at 207,774,520. Meanwhile, there are 10,418 transgenders in Pakistan. Percentage wise men form $51 \%$, women $48.76 \%$ and transgender $0.24 \%$ of the total population of Pakistan.

Pakistan's ministry of finance has provided education affairs and services with Rs. 97.42 billion in the budget estimates 2018-19 as compared with Rs. 90.516 billion in budget estimates 2017-18. The bulk of expenditure at Rs71.824 billion has been allocated for Tertiary Education Affairs and Services in budget 2018-19, which is 73.7 percent of the total allocation under this head (Yusufzai, 2018). According to the data of Pakistan Council of Science and Technology, the gender wise enrollment in public universities; females are not more less in numbers in this regard, they are getting enrolled in universities for higher studies, but when we see at rate of labor force participation, the results are very shocking. According to The World Bank out of total population of Pakistan only $69.96 \%$ are part of labor force. This proportion is very depressing as remaining $30.04 \%$ of the total population is economically dependent; this means that they are burden on economy. According to the record of Pakistan Bureau of Statistics, females make around $48.76 \%$ of the population; and from this $48.76 \%$ only $24.93 \%$ are currently part of labor force of the economy.

These statistics show that female population of Pakistan are literate, they are enrolled in public educational institutions; which means that they are using the allocated amount of national budget but after completing their education they are not paying back that consumed amount to the country. This has also made educated women as economically burdensome on family because they do not take part in economic activities (Boserup, 2007).

According to Pakistan Bureau of Statistics (2017), Pakistan population is comprised of $207,774,520$ from this number of total population $48.76 \%$ percent are women. Economic growth of any country rely on the labor force participation of that country; this means that majority of the population, including men and women should work and participate in the labor activities of the country. In case of Pakistan, the ratio of labor force participation is very miserable. In Pakistan, women employment is low as compare to men's. (Dale, Fieldhousem, Shaheen \& Karlra, 2002). Women employment in Pakistan has increased a bit when we compare it from past; they have increased their paid work participation, but there are many forces which are resulting in this situation (Alvarez \& Miles, 2006). Study conducted by Ferrero \& Bustillos (2007), indicated that traditional roles, associated with any gender continues to affect the younger residents of any society. Women are expected to be more obedient 
and relationship oriented than men and men are projected to be destructive and aggressive (Chaplin, Cole \& Waxler, 2005) and these traditional roles continue to be the part of people's lives even after marriage (Sanchez \& Hall, 1999). This is also because parents spend most of their time with the same-sex offspring and that puts influence over gender socialization of kids (Mchale, Crouter \& Whiteman, 2003). This theory was also approved in 2012, in a study conducted by Bianchi, Sayer, Milkie \& Robinson, that daughters are more similar to their mothers as they anticipate their family, childbearing, housework and career future. Experiences, skills and capabilities developed in early childhood can influence decision making, behavioral patterns, attitudes and self-development (Hale et al., 2003). Lee \& Porfeli (2015) stated that youth's perception regarding career choices of any society is largely influenced by their parents' work experiences. This is also because of duties of married women as a mother are so challenging and tiring that they find it difficult and, in many cases, impossible to continue their jobs after child bearing (Mincer, 1962).

Another major reason behind lack of women employment in Pakistan is the mindset that consider men as primary breadwinner and women are primarily responsible for house chores and other domestic activities. Potuchek (1992) also claimed in his study that majority women consider their husbands' jobs more important than theirs. For this reason also women are ready to quit their jobs for the sake of family. Religion here also place a pivotal role. Most of the religious clerics in impart the values which priorities male economic independence and female economic dependence, until or unless they face any financial need (Pal, 1990). This is also a reason that women are by will ready to pursuit their lives as housewives; without feeling of any stress and depression, whereas unemployment is the condition in which married men are found more in stress and depression as compared to married women (Radloff, 1975). Additional motive behind low female employment is unsafe environment. Women and young gilrs do not feel safe outside their homes and they prefer to stay home (Richman et al., 1999).

\section{Methodology}

Present study is descriptive in nature as the aim of study is just to describe the situation. It is not to make any accurate prediction and to determine any cause and effect relationship. Researcher has collected quantitative data because it is clear, specific and can be easily communicated via charts and graphs. Online survey was conducted for data collection via Google form; as this method of data collection is two-thirds shorter, cheaper, more accurate and easier to analyze than that of traditional research methods. Total 160 responses were collected through convenient sampling, which is based on availability of respondents to the investigator rather than selecting subjects at random from the entire population and to complete data collection in shorter period of time. The survey form was circulated in different Facebook closed groups like Soul Sisters Pakistan. Majority of the responses were collected from girls of 15-20 age group.

No statistical test has been applied on the data, as this study is only representing the differences in responses. Survey form was filled by all females, from which $25.62 \%$ were doing their matriculation, $45 \%$ intermediate, $15.62 \%$ bachelors, $9.37 \%$ masters and only $3.7 \%$ were doing their M.Phil. and Ph.Ds. This means that the data will illustrate the perception of female youth of Pakistan; who are energetic, enthusiastic and oriented for their future. These respondents are unmarried which means that they have no experience regarding professional and domestic life. This means that their responses depend majorly on their gender socialization and parents and social circle's attitudes towards the concept.

\section{Results}

The survey form was posted in Pakistan based social media closed groups, therefore most of the responses we got were from Muslims. From the total of 160 respondents, 154 belong to religion Islam, 1 was Hindu, 1 Christianity and remaining 2 were non-believer. This means that the responses filled are in reflection of Islamic ideologies and the practices done by Muslims.

Question was asked about the economic independence status of respondents' mothers. Only 50 respondents had mothers who are economically independent, remaining 110 respondents had mothers who are dependent on their husbands.

Unmarried respondents were 115 , as they were majority girls of age 15-20 years. Engaged were 17, 27 were married and only 1 was divorced. As majority respondents were unmarried, so they have no idea about the marital life and the problems faced by married working women. All of the major part of responses are reflection of gender socialization and the exposure which these 132 young girls. 


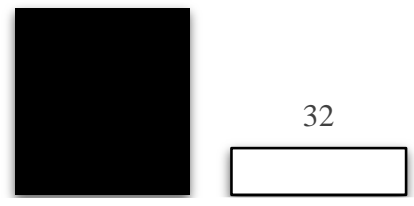

- Passionate $\square$ Societal Pressures

Figure 1: Selection of career due to passion or societal pressure

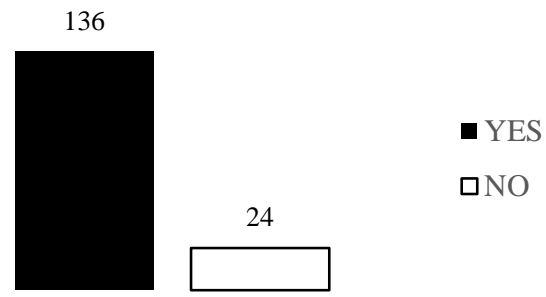

Figure 2: Women should do job without any financial need

These graphs are showing that mainstream respondents are pursuing their education with passion and for the desire for being someone better in life, and in the next figure we can observe that these respondents showed positive remake on economic independence of women, with or without any financial needs.

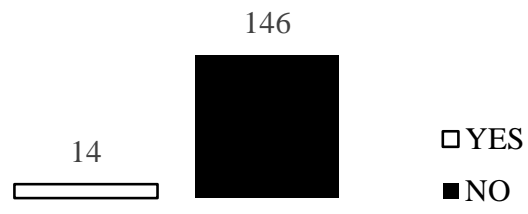

Figure 3: Women should quit their jobs after marriage

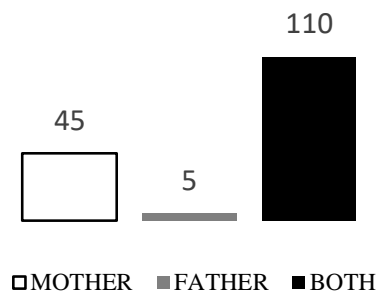

Figure 4: Holding Child Rearing Responsibility

These reactions are displaying the mindset of Pakistani educated women. According to 146 respondents, marriage should not become a hindrance in the economic activities of women and they should continue their profession after their marriages. Not only marriage but bearing and rearing children should also not stop them from doing so, as only 45 said that it is only mother's responsibility of taking care of children but majority of 110 said that it is both father's and mother's responsibility, to divide their tasks and take care of children together. 
141

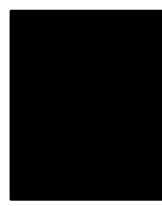

19

$\square$ NO

Figure 5: Difficult for women to continue with job after a child

88
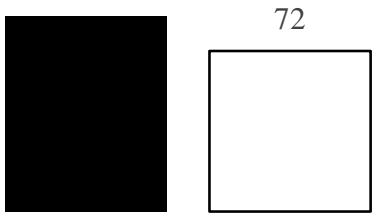

- YES

$\square \mathrm{NO}$

Figure 6: Uncomfortable feeling while working with men

These graphs are demonstrating the reasons behind lack of participation. The same respondents who said that they are keen about their studies and eager to be part of economic activities in future, gave alternate responses when asked about doing job after giving birth to a child; as 141 said that it is difficult for women to continue with job after a child. The other graph (Figure 6) is explaining respondents say on working with males; as this survey was majorly filled by girls of as 15-20. These 104 respondents are students of matriculation and intermediate who are studying in only girls' school and college.

\section{6}

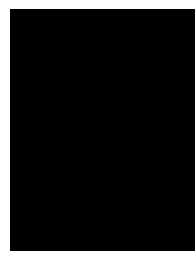

- YES

34

$\square \mathrm{NO}$

Figure 7: Working environment unsafe for women

139

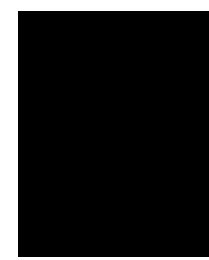

- YES

21

$\square \mathrm{NO}$

Figure 8: Is Public transport unsafe for women

Figure $7 \& 8$ are demonstrating about the security issues. When asked respondents about the working environment conditions; 126 declared it unsafe for women (Figure 7) and 139 claimed public transport system unsafe for them (Figure 8). 


\section{Discussion}

The results showed that majority of the respondents are enthusiastic and motivated about their education and career; they have definite plans for their future and they fully showed affirmative response on doing job without any financial need (Figure 2). This is giving clue that these Pakistani female youth is passionate about their education and they are career oriented; which will lead these women to take part in economic labor participation, because women are able to grab successful position in male dominated structure, just with immense commitment, energy and emotion (Loy, 2003), but opposite and unexpected replies were given when asked about doing job after marriage. It is not because of their experiences; as young girls of this age make their decisions on the bases of observing their family and social circle and adolescence is the key age for the growth of gender socialization which is the expectation of appropriate behavior according to gender (Montanes et al., 2012).

Majority respondents' mothers having non-working profile affect response rate because daughters in a way idealize and adopt the practices of their mothers (Bianchi et al, 2012). The bond shared by mothers and daughters is the strongest out of any family members and mothers are solely responsible to teach their girls how to grow up. They are their guide, confidant and friend. Respondents showed negative response on working with males and they have declared public transport services insecure; which may be also because of encountering males (Figure $6)$.

As mentioned earlier, most respondents were from educational institutions which are only for girls. This means that these respondents do not have experiences of performing any formal activity with males (Figure $6 \& 7$ ). Due to their lack of experience in encountering males; they have shown resistance in working with them; and in Pakistan due to Islamic religious values and beliefs families prefer their girls to avoid unnecessary contact with males and these practices in turn put negative effect on material culture of the present world in a way that; they are providing some sort of protection to women, but may actually constraining their urban mobility (Secor, 2010).

It is harsh reality of our society that every next second women face sexual harassment; whether it is academic setting or professional; which affects women's overall wellbeing (Swanberg \& Logan, 2005).

\section{Conclusion}

This survey has conducted to find the major reasons for low women labor force participation; which is one of the major causes behind low rate of economic growth in Pakistan. The survey concluded that, women in Pakistan, especially the female youth, is energetic, motivated, visionary and goal oriented. They have high aims for their career and professional development, but there are some sociocultural values and practices which pull out women's leg in this race. Pakistan is a country where Islamic religious values and beliefs are given pivotal position and every matter of life, and these Islamic values have prioritized family as the most primary institution in every Islamic society and for this primary institution; and for this primary institution role of women has given a great importance. Women here are expected to stay and home and look for the domestic affairs and duties, whereas, men as kept responsible for taking care of bread and butter. Due to these values; women in Pakistan are obliged to perform this traditional role from decades and the transfer these values to their same off springs in the form of gender socialization. Another factor behind this disparity is the unsafe environment for women; which is forcing women to avoid evolving in any economic activity which is outside home.

\section{Conflict of interest}

Author declares that she has no conflict of interests related to this research paper.

\section{Acknowledgement}

This survey was supported by Habib Girls' Schools, as they allowed me to collect data from their premises. I would also like to thank my students especially, Aqsa Mahmood, Habiba Moin, Mishal Abid, Mahrukh Hassan and Sherebanu Huzaifa who helped me in data collection process for all their constructive comments and wise suggestions.

\section{Funding}

None.

\section{References}

- Alvarez, B., \& Miles, D. (2006). Husbands housework time: Does wives paid employment make a difference? Investigaciones Económicas, 30, 5-31.

- Bianchi, S. M., Sayer, L. C., Milkie, M. A., \& Robinson, J. P. (2012). Housework: Who did, does or will do it, and how much does it matter? Social Forces, 91, 55-63.

- Chaplin, T.M., Cole, P.M., \& Zahn-Waxler, C. (2005). Parental socialization of emotion expression: gender differences and relations to child adjustment. Emotion, 5, 80-88.

- Dale, A., Fieldhouse, E., Shaheen, N., Kalra, V. (2002). Labour market prospect of Pakistani and Bangladeshi women. Sage Journals, 16(1). Retrieved from https://journals.sagepub.com/

- Lee, B., \& Porfeli, E. J. (2015). Youths' socialization to work and school within the family. International Journal for Educational and Vocational Guidance, 1-18. 
- McHale, S. M., Crouter, A. C., \& Whiteman, S. D. (2003). The family contexts of gender development in childhood and adolescence. Social Development, 12(1), 125-148.

- McHale, S. M., Crouter, A. C., \& Whiteman, S. D. (2003). The family contexts of gender development in childhood and adolescence. Social Development, 12(1), 125-148.

- Mincer, J. (1962). Labor Force Participation of Married Women: A Study of Labor Supply. National Bureau of Economic Research, 62(2), $63-105 . \quad$ Retrieved from https://www.nber.org/chapters/c0603.pdf

- Montañés, P., de Lemus, S., Bohner, G., Megías, J. L., Moya, M., \& Garcia-Retamero, R. (2012). Intergenerational transmission of benevolent sexism from mothers to daughters and its relation to daughters' academic performance and goals. Sex Roles, 66(7-8), 468-478.

- Pakistan bureau of statistics. (2017). Population census. Retrieved from http://www.pbs.gov.pk/

- Pakistan bureau of statistics. (2018). Retrieved from http://www.pbs.gov.pk/content/labourforce-statistics

- Pal, I. D. (1990). Women and Islam in Pakistan. Middle Eastern Studies, 26(4), 449-464.

- Potuchek, J. L. (1992). Employed wives' orientations to breadwinning: A gender theory analysis. Journal of Marriage and the Family, 548-558.

- Radloff, L. (1975). Sex differences in depression: The effects of occupation and marital status. Sex Roles, 1(3), 249-265.
- Richman, J. A., Rospenda, K. M., Nawyn, S. J., Flaherty, J. A., Fendrich, M., Drum, M. L., and Johnson, T. P. (2011). Sexual harassment and generalized workplace abuse among university employees: prevalence and mental health correlates. American Journal of Public Health. Retrieved from https://ajph.aphapublications.org/

- Sánchez, L., \& Hall, C. S. (1999). Traditional values and democratic impulses: The gender division of labor in contemporary Spain. Journal of Comparative Family Studies, 30, 659-685.

- Secor, J., A. (2002). The Veil and Urban Space in Istanbul: Women's dress, mobility and Islamic knowledge. Gender, Place \& Culture, 9(1), 5-22.

- Silván-Ferrero, M. P., \& Bustillos López, A. (2007). Benevolent sexism toward men and women: Justification of the traditional system and conventional gender roles in Spain. Sex Roles, 57, 607-614.

- Swanberg, J. E., \& Logan, T. K. (2005). Domestic violence and employment: a qualitative study. Journal of occupational health psychology, 10(1), 3.

- Yusufzai, A. (2018). Education Budget for Fiscal Year 2018-19 Announced. Retrieved from

https://propakistani.pk/2018/04/28/educationbudget-for-fiscal-year-2018-19-announced/ 